\title{
Impact Assessment of Improved Technology on Soybean Productivity in South Eastern Rajasthan, India
}

\author{
D.S. Meena ${ }^{1 *}$, Chaman Jadon ${ }^{1}$, C.B. Meena ${ }^{2}$, B.S. Meena ${ }^{1}$, \\ B.L. Meena ${ }^{3}$ and B.K. Patidar ${ }^{4}$ \\ ${ }^{1}$ Agronomy, ${ }^{2}$ Plant Pathology, ${ }^{3} \mathrm{PBG},{ }^{4}$ Entomology, Agricultural Research Station, Agriculture \\ University Kota, Ummedganj Farm, Kota 324 001, Rajasthan, India \\ *Corresponding author
}

\section{A B S T R A C T}

\section{Keywords}

Farmers practices,

Frontline

demonstration,

Improved

technology,

soybean,

sustainability value

index, sustainability

yield index

\section{Article Info}

Accepted:

06 June 2018

Available Online:

10 July 2018
To demonstrate the new production technologies to farmers the front line demonstration is very important tool. The frontline demonstration were conducted during 2011-12 to 2017-18 on farmers' field in the Zone V to show performance of soybean production improved technology recommended by Agriculture University Kota. The results of improved technologies were more remunerative to farmers as compared to farmers' practices. Use of improved technology for soybean production helps to increase the productivity of soybean by 16.64 per cent over farmers practice. In term of monetary returns, 19.22 per cent increase was observed as compare to farmers' practice. Similarly improved technologies exhibited higher value of Sustainable Yield Index and Sustainable Value Index in most of the years.

\section{Introduction}

Among the oilseeds crops, soybean is a leading oilseed crop in world as well as in India. Soybean productivity is oscillating between 1.0 to $1.7 \mathrm{t}$ per ha in past few years as compared to major soybean growing other countries (2.7 t/ha). Soybean (Glycine max) is an important rainy season crop grown more than 0.92 mha in south eastern parts of Rajasthan mainly in Kota, Bundi, Baran and
Jhalawar districts producing $0.75 \mathrm{mt}$ with average productivity of $811 \mathrm{~kg} / \mathrm{ha}$ which is very low compared to national productivity of $1153 \mathrm{~kg} / \mathrm{ha}$ of India (Anon 2017). Soybean belongs to the Leguminaceae family, is recognized as golden or miracle bean as it have high nutritive value and various uses viz., for feed, oil and soy food products. It is also rich in protein (38-42\%) and contains 1822 per cent edible oil. The crop plays an important role in India oil economy and 
foreign earnings among nine major oilseed crops. During 2009-10 it contributed 40 and 23 per cent to total oilseeds and edible oil production of the country and earned valuable foreign worth (4, 258 crores) from exporting soya meal. During 2009-10, the export of soybean meal was reduced as compared to previous year (7, 485 crores) on account of several reasons. In Rajasthan state the average productivity of soybean is very low in comparison to potential realization. Among the different reason for low productivity the research emanated technologies have not yet reached to the farmer's field is very important. The prevailing climatic conditions (precipitation between 500 and $700 \mathrm{~mm}$ during last week of June to September) and soil conditions (heavy black with medium nitrogen and phosphorus, and high potassium contents) supports soybean cultivation in humid South East Rajasthan (Zone-V), concerted efforts are needed to take the production technologies to farmers. Keeping this in view, the present front line demonstrations were conducted at farmer's fields under AICRP on Soybean (ICAR) during 2011 to 2017 with financial assistance from Ministry of Agriculture and Cooperation, Government of India to demonstrate improved technologies of soybean production for enhancement of soybean productivity and income generation in South East Rajasthan under farmer's field conditions.

\section{Materials and Methods}

A total of 90 frontline demonstrations were carried out in the last seven year (2011-12 to 2017-18) during kharif season at farmer field of Kota, Bundi, Baran and Jhalawar districts. Every demonstration was laid out in an area of 0.4 ha with improved package of practices involving high yielding varieties (JS 95-60, JS 93-05 and RKS 24), seed treatment with Thiram (2.0 g) + Carbendazim (1.0 g) per kg seed, rhizobium culture @ $5 \mathrm{~g}$ per kg seed and PSB culture @ 5 g per kg seed, recommended dose of fertilizers (N:P:K:S 20:40:40:30 $\mathrm{kg} / \mathrm{ha}$ ), weed management (hand weeding, imazeythpyr $0.750 \mathrm{~kg}$ per ha as postemergence spray and chlorimuron ethyl $9.37 \mathrm{~g}$ per ha as post emergence spray), plant protection (one spray of monocrotophos @ $1000 \mathrm{ml}$ per ha followed by one spray of quinalphos@700 ml per ha), crop geometry $(30 \mathrm{~cm} \times 10 \mathrm{~cm})$, seed rate $(80-100 \mathrm{~kg} / \mathrm{ha})$. The results for 90 FLDs carried out from 2011-12 to 2017-18 were analyzed and compared with farmers practice. Farmers were allowed to follow their own production technology which involved traditional practices (use their own seed of local variety, no seed treatments and imbalance NPK application, hand weeding only, no prophylactic control measures for pest and diseases, chemical plant protection after the appearance of insect pest, improper spacing and higher seed rate $120 \mathrm{~kg} / \mathrm{ha}$ ). Data recorded on seed yield and net returns were statistically analyzed for calculation of parameters like standard deviation and coefficient of variation as per standard procedure (Panse and Sukhatme, 1978). Sustainability indices (Sustainability Yield Index, Sustainability Value Index) were worked out using following formula: SYI / SVI = Y/V-SD / Y $\max$. Where, $\mathrm{Y} / \mathrm{V}$ is estimated average yield/net return of practice over year (study period), SD is standard deviation and $\mathrm{Y}$ max is observed maximum yield/maximum net return during the study period (Singh et al., 1990).

\section{Results and Discussion}

The data in table 1 on average yield obtained in demonstration field by using given package of improved technologies of soybean cultivation was $1622 \mathrm{~kg}$ per ha, whereas, it was $1394 \mathrm{~kg}$ per ha from farmer's practices. This result revealed that adoption of improved production technologies for soybean cultivation enhanced productivity by 16.64 per cent as compare to farmers practice. 
Table.1 Performance of improved technologies of soybean production through frontline demonstrations

\begin{tabular}{|c|c|c|c|c|c|c|c|}
\hline \multirow[t]{2}{*}{ Partculars } & \multicolumn{7}{|c|}{ Years } \\
\hline & 2011 & 2012 & 2013 & 2014 & 2015 & 2016 & 2017 \\
\hline Number of Demonstration & 10 & 10 & 10 & 10 & 10 & 20 & 20 \\
\hline Meen Seed yield (kg/ga) IT & 2094 & 1847 & 1596 & 1655 & 1060 & 1449 & 1656 \\
\hline Meen Seed yield (kg/ga) FP & 1849 & 1547 & 1352 & 1408 & 898 & 1241 & 1461 \\
\hline Increase in seed yield IT (Rs./ha) & 13.27 & 19.37 & 18.09 & 17.74 & 17.98 & 16.78 & 13.28 \\
\hline Mean Gross Return IT (Rs./ha) & 46068 & 60935 & 52668 & 54599 & 34964 & 40210 & 45940 \\
\hline Mean Gross Return FP(Rs./ha & 40667 & 51035 & 44616 & 46448 & 29634 & 34431 & 40555 \\
\hline Mean Net Return IT (Rs./ha) & 31850 & 40002 & 32891 & 32397 & 12407 & 17653 & 24871 \\
\hline Mean Net Return FP(Rs./ha & 27779 & 33035 & 26611 & 27058 & 10041 & 14838 & 21738 \\
\hline Additional return over FP & 5401 & 9900 & 8052 & 8151 & 5330 & 5779 & 5385 \\
\hline ICBR ratio & 4.06 & 3.38 & 4.54 & 2.90 & 1.80 & 1.95 & 2.39 \\
\hline
\end{tabular}

IT: Improved technology, FP: Farmers practices, and ICBR: Incremental cost benefit ratio

Table.2 Variability in seed yield and net return in soybean front line demonstration

\begin{tabular}{|c|c|c|c|c|c|c|c|c|c|c|c|c|c|c|}
\hline \multirow[t]{2}{*}{ Particulars } & \multicolumn{2}{|c|}{ Kharif 2011} & \multicolumn{2}{|c|}{ Kharif 2012} & \multicolumn{2}{|c|}{ Kharif 2013} & \multicolumn{2}{|c|}{ Kharif 2014} & \multicolumn{2}{|c|}{ Kharif 2015} & \multicolumn{2}{|c|}{ Kharif 2016} & \multicolumn{2}{|c|}{ Kharif 2017} \\
\hline & IT & $\mathrm{FP}$ & IT & FP & IT & FP & IT & $\mathrm{FP}$ & IT & FP & IT & FP & IT & $\mathrm{FP}$ \\
\hline $\begin{array}{l}\text { Seed yield Range } \\
\text { (kg/ha) }\end{array}$ & $\begin{array}{l}1750- \\
2420\end{array}$ & $\begin{array}{l}1560- \\
2175\end{array}$ & $\begin{array}{l}1600- \\
2080\end{array}$ & $\begin{array}{l}1350- \\
1750\end{array}$ & $\begin{array}{l}1400- \\
1820\end{array}$ & $\begin{array}{l}1175- \\
1550\end{array}$ & $\begin{array}{l}1450- \\
1850\end{array}$ & $\begin{array}{l}1220- \\
1570\end{array}$ & $\begin{array}{l}845- \\
1200\end{array}$ & $\begin{array}{l}725- \\
1025\end{array}$ & $\begin{array}{c}1170- \\
1750\end{array}$ & $\begin{array}{l}1010- \\
1500\end{array}$ & $\begin{array}{c}1370- \\
1921\end{array}$ & $\begin{array}{l}1210- \\
1760\end{array}$ \\
\hline Mean & 2094 & 1849 & 1847 & 1547 & 1596 & 1352 & 1655 & 1408 & 1060 & 898 & 1449 & 1241 & 1656 & 1461 \\
\hline Standard Deviation & 220.5 & 190.7 & 164.5 & 132.1 & 154.7 & 132.2 & 138.7 & 142.0 & 114.2 & 95.8 & 163.7 & 139.9 & 163.6 & 147.7 \\
\hline $\begin{array}{l}\text { Net Retun range } \\
\text { (Rs/ha) }\end{array}$ & $\begin{array}{l}24282- \\
39682\end{array}$ & $\begin{array}{l}21432- \\
34412\end{array}$ & $\begin{array}{l}31867- \\
47707\end{array}$ & $\begin{array}{l}26550- \\
39750\end{array}$ & $\begin{array}{l}26423- \\
40283\end{array}$ & $\begin{array}{l}20770- \\
33145\end{array}$ & $\begin{array}{l}25648- \\
37198\end{array}$ & $\begin{array}{l}20870- \\
32420\end{array}$ & $\begin{array}{l}5328- \\
17043\end{array}$ & $\begin{array}{l}4332- \\
14232\end{array}$ & $\begin{array}{l}9911- \\
26006\end{array}$ & $\begin{array}{l}8435- \\
22032\end{array}$ & $\begin{array}{l}16949- \\
32239\end{array}$ & $\begin{array}{l}14761- \\
30023\end{array}$ \\
\hline Mean & 31850 & 27779 & 40002 & 33035 & 32897 & 26611 & 32397 & 27058 & 12407 & 10041 & 17653 & 14838 & 24871 & 21717 \\
\hline Standrad Deviation & 4843.28 & 4194.79 & 5426.9 & 4358.60 & 5106.30 & 4394.63 & 4576.88 & 4685.83 & 3768.65 & 3160.66 & 3221.28 & 2751.62 & 2851.47 & 2968.66 \\
\hline CV \% & 15.20 & 15.10 & 13.56 & 13.19 & 15.29 & 15.10 & 14.13 & 17.32 & 30.38 & 31.48 & 18.24 & 18.55 & 11.47 & 13.67 \\
\hline SYI & 0.774 & 0.771 & 0.809 & 0.809 & 0.792 & 0.786 & 0.842 & 0.806 & 0.788 & 0.783 & 0.734 & 0.698 & 0.777 & 0.763 \\
\hline SVI & 0.692 & 0.685 & 0.725 & 0.721 & 0.690 & 0.670 & 0.716 & 0.660 & 0.593 & 0.585 & 0.504 & 0.549 & 0.631 & 0.624 \\
\hline
\end{tabular}


Meena et al., (2011) reported that 23.32 per cent increase in yield under improved technologies was observed over farmers practices, Bhatnagar (2001) reported that the research emanated production technologies were capable of enhancement of productivity of soybean by 32.26 per cent through frontline demonstration. Similarly, Raghuwanshi et al., (2009) also observed a 16.64 per cent enhancement in the productivity of soybean by adoption of improved technology over farmers practices. Similar yield enhancement in frontline demonstrations conducted in other crops has been documented (Kumar et al., 2010; Dhaka et al., 2010). In an economic evaluation, per hectare net return of Rs. 27439 per ha was obtained in demonstration plots, while Rs. 23014 per ha were obtained in farmers practice. The data clearly indicated that additional more net return of Rs 6857 per ha over farmers practice was obtained in FLD. Though the cost of cultivation was more Rs.2433 in demonstrations over farmers practices, but there was an increase in net returns was 19.22 per cent. (Table 2). Similarly Raghuwanshi et al., (2010) also observed 20.01 per cent higher net returns our farmers practice in soybean front line demonstrations. Further, improved technologies exhibited higher value of sustainability indices (SYI and SVI) for all the years except 2016, due to a heavy infestation of the crop with yellow mosaic virus followed by charcoal rot, which ultimately reduced production potential and resulted in lower SVI. However, overall mean of 7 years study period for sustainability parameter was also of higher magnitude with improved technologies as compared to farmer's practices because of higher standard deviation values due to variation in crop conditions, response to inputs and also depended upon varying situation of cultivation. Similar observation was also observed by Dubey and Ali (1999) and
Kumar and Ali (2002) in linseed front line demonstrations. It is concluded that cultivation of soybean with improved technology adopted in frontline demonstrations at farmer field was more profitable compared to the crops grown by using farmer's practices. Sustainability parameter like SYI and SVI were also higher in improved technologies during the study period. Thus, the present investigation proved that improved technology for soybean cultivation offered higher yield and profit as compared to farmers practice. The sustainability parameters like SYI and SVI were higher with improved technologies during most of the years under study. Soybean productivity can be enhanced by adopting improved production technology.

\section{References}

Anonymous, 2017. Directors report and summary tables of experiments 2017. All India Coordinated Research Project on Soybean, ICAR- Indian Institute of Soybean Research, Indore, Madhya Pradesh pp. iv

Bhatnagar P. S., 2009. Harnessing productivity and profitability potentials of soybean (Glycine max) for its sustainability in India. In: Abstracts: Developing a Global soy blueprint for a Safe, Secure and Sustainable Supply, WSRC. 2009, August 10-15, Beijing, China, pp.209.

Bhatnagar P. S., 2001. Present status of soybean in India and strategies for its sustainable farming and industry. Paper presented in Indian Soy Forum 2001, March 17-18, 2001.

Dhaka, B. L., B. S. Meena, and Suwalka, R. L. 2010. Popularization of improved maize production technology through frontline demonstration in South Eastern Rajasthan. Journal of Agriculture Sciences 1(1): 39-42. 
Dubey, C. S., and Mashiat Ali, 1999. Yield economics and sustainability parameters in linseed frontline demonstrations in Kota Division. Journal of Oilseeds Research 16(2), 1999: 306-9

Kumar S R and Mashiat Ali. 2002. Sustainability and economics of linseed (Linum usitatissimum) frontline demonstration in Rajasthan. Extended Summaries Vol. 2: 2nd International Agronomy Congress, Nov.26-30, 2002, New Delhi, India. pp 1459-60.

Kumar, A., R. Kumar, V.P.S. Yadav, and Kumar, R. 2010. Impact assessment of frontline demonstrations of Bajra in Haryana State. Indian Research Journal of Extension Education 10(1): 105-8.

Meena, D.S., M. Ali, B. Ram, and Tetarwal, J.P. 2012. Impact of Improved Technology on Soybean Productivity in South Eastern Rajasthan Soybean Research 10: 99 - 103
Panse, V. G. and Sukhatme, F. V. 1978. Statistical Methods for Agricultural Workers. Indian Council of Agricultural Research, New Delhi.

Raghuwanshi, S. R. S., O. P. S. Raghuwanshi, R. Umat, G. R. Ambawatia and Bhargav, K. S. 2009. Impact of Improved Technologies on Soybean Productivity. Haryana Journal Agronomy 25(1 \& 2): 82- 3 .

Raghuwanshi, S. R. S., O. P. S. Raghuwanshi, R. Umat, G. R. Ambawatia and Bhargav, K. S. 2010. Productivity enhancement of soybean (Glycine max (L.) Merrill) through improved technology in farmers field. Soybean Research 8: 85-88.

Singh, R. P., S. K. Das, U. M. Bhaskara Rao, and Narayana Reddy, M. 1990 Towards sustainable dryland agricultural practices. Technical Bulletin, Central Research Institute for Dryland Agriculture, Hyderabad, pp $1-106$.

\section{How to cite this article:}

Meena, D.S., Chaman Jadon, C.B. Meena, B.S. Meena, B.L. Meena and Patidar, B.K. 2018. Impact Assessment of Improved Technology on Soybean Productivity in South Eastern Rajasthan, India. Int.J.Curr.Microbiol.App.Sci. 7(07): 728-732. doi: https://doi.org/10.20546/ijcmas.2018.707.089 